\title{
ERBB2 NM_004448.2p.2324_2325ins12
}

National Cancer Institute

\section{Source}

National Cancer Institute. ERBB2 NM 004448.2p.2324 2325ins12. NCI Thesaurus.

Code C98361.

An insertion of 12 nucleotides, AT ACGT GAT GGC, between position 2324 and 2325 of the coding sequence of the ERBB2 gene. 